\title{
Language Policy and National Feeling in Context Ukraine's Euromaidan, 2014-2016
}

\author{
Csilla FEDINEC \\ István CSERNICSKO
}

\begin{abstract}
Ukraine is the best example of "nationalizing" nationalism. During its twenty-five year old existence the language question - in addition to historical approach and ethnical identity - has belonged to the unclosed questions of personal and group identity, and represents one of the central themes of political struggle. Official Ukrainian language policy permanently wants to promote the use of Ukrainian or Russian by overshadowing one or the other. Measures regulating language use have never been consequently applied, which fact in itself is enough to represent a permanent subject for political campaigns. Political powers unable to solve actual economic and social problems wanted to distract attention by this means. That is why the politicized language question could contribute to the political crisis and the outbreak of the armed conflict at the end of 2013 and at the beginning of 2014 in a politically unstable country facing economic breakdown. The present paper examines the role of the language question in the Ukrainian crisis in the period of 2014-2016.
\end{abstract}

\section{Keywords}

Ukraine, Euromaidan, crisis, national identity, language policy

The word "crisis" is used to define situations, when the life (or functioning) of an individual, a community, a company or a state is threatened by a serious turmoil or difficult situation which decisively influences the present as well as the future. ${ }^{1}$ In the brief history of Ukraine which gained its independence 25 years ago in 1991, the country had to face numerous crises. Constitutional, political, economical, demographical crises are closely linked to the history of the state. At the turn of 2013-2014 such crisis evolved in Ukraine that it outgrew its borders. Ukraine lost control over more than $11 \%$ of its area (The area of Ukraine is $603,500 \mathrm{~km}^{2}$; the area of the Crimea is cca. 27 thousand $\mathrm{km}^{2}$ and armed conflict territory in the Donbass region is cca. 42 thousand $\mathrm{km}^{2}$.) The annexation of the Crimea, the eastern Ukrainian armed conflict endangers the balance of the world's security policy, now the political and economic sanctions against Russia and the responding opposing sanctions are obstructing the growth of world economy. ${ }^{2}$ Some analysts do not only talk about different

1 Online: http://dictionary.cambridge.org/dictionary/english/crisis (Downloaded 22 April 2017).

2 MARIONI, Max: The cost of Russian sanctions on Western economies, in: BOW Group Research Paper: The Sa- 


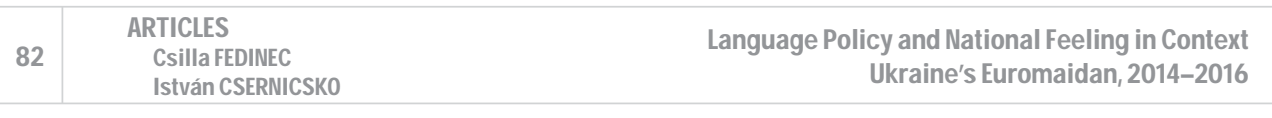

crises in the case of Ukraine, but use an overall term: "Ukrainian crisis". Sakwa describes the events in spring 2014 as the amount of two enormous crises, according to him "a common European and a Ukrainian crisis has led to this destructive consequence". ${ }^{3}$ Thus the exact definition of the eastern Ukrainian armed conflict still has not happened yet the war is often euphemistically called "Ukrainian crisis" by the analysts. ${ }^{4}$

The ethno-linguistic composition and language orientation of the regions with various historic backgrounds (e.g. Donbas, Crimea, Galicia, Bukovina, Transcarpathia) greatly differed already before Ukraine's independence. The initial euphoria, however, concealed these differences. Having become independent, Ukraine faced a major problem: "What will the new identity be based on?"

The particular characteristics of the geopolitical and geographical position of Ukraine, the variable political, historical, economic, cultural and social development of the regions of its territory inherited from the Soviet Union, the ethnic and linguistic composition of its population, and the fact that the representatives of the titular nations of all neighboring states are among its citizens all turn issues of language into matters of internal and foreign policy as well as of security policy in this country. The military conflict (hybrid war) currently underway is also indicative of this. According to Grin language policy is a systematic, rational and scientific activity which aims at changing the linguistic environment in order to increase well-being. ${ }^{5}$ Taking into account this statement, one can be certain that Ukrainian language policy is doomed to failure. Following the demand set by Grin's definition has proven to be very challenging task in the case of Ukraine.

\section{Typology of the Crises}

In its brief history Ukraine had to face numerous crises. Constitutional, political, economic, demographical crises are closely linked to the history of the state.

- Economic crisis. When the Soviet Union was near to collapse, it was obvious that - as for economic, military and demographic importance - Ukraine would be the second most significant successor state preceded only by Russia. However, besides Kyrgyzstan Ukraine is the only post-soviet country that has not reached its last GDP as a member of the Soviet Union yet. In 2009 Ukrainian GDP was still not more than $63.3 \%$ of the GDP of 1990, the last full Soviet year. ${ }^{6}$ The Ukrainian conflict, that has now been lasting

nctions on Russia, August 2015, 16-31.; online: http://data.worldbank.org/country/russian-federation?view=chart (Downloaded 22 April 2017).

3 See SAKWA, Richard: Frontline of Ukraine: Crisis is the Borderlands, I.B. Tauris 2014.

4 LARUELLE, Marlene:The Ukrainian Crisis and its Impact on Transforming Russian Nationalism Landscape, in: Ukraine and Russia: People, Politics, Propaganda and Perspectives, WILCZEWSKA, Agnieszka P. - SAKWA, Richard (Eds.), E-IR Info 2015, 123-128.; RUTLAND, Peter: An Unnecessary War: The Geopolitical Roots of the Ukraine Crisis, in: E-International Relations, 2015, online: http://www.e-ir.info/2015/04/09/an-unnecessary-warthe-geopolitical-roots-of-the-ukraine-crisis/ (Downloaded 22 April 2017); KISSINGER, Henry: To Settle the Ukraine Crisis, Start at The End, in: The Washington Post, 5 March 2014, online: http://www.washingtonpost.com/ opinions/henry-kissinger-to-settle-the-ukraine-crisis-startat-the-end/2014/03/05/46dad868-a496-11e3-8466d34c451760b9_story.html (Downloaded 22 April 2017).

5 GRIN, François: Language Policy Evaluation and the European Charter for Regional or Minority Languages, Palgrave Macmillan 2003, 30.

6 SHUL'GA, Nikolaj: Дрейфр на обочину. Двадиать лет общественных изменений в Украине [Drejf na obočinu. Dva- 
for two years (due to the sanctions and opposing sanctions) is obstructing the economic growth that could be barely reconstructed after the 2008 economic crisis, not only in Ukraine but all over the world. Ukrainian GDP significantly reduced in 2014 and 2015 , the country lost $21 \%$ of its industrial capacity. ${ }^{7}$

- Constitutional crisis. Through 5 years until 1996 the country functioned based on the scant constitution of Soviet-Ukraine, and the Constitution that was accepted after numerous political struggles has been rewritten several times since then. Up to 2014 the most important modifications reflected the polemics on presidential power. After the second Maidan one of the basic promises of the new ruling power was decentralization - this way trying to solve the Donbass conflict as well. ${ }^{8}$ Up to now three international documents were signed to solve the situation: the Minsk $1^{9}$ and the Minsk Memorandum ${ }^{10}$ in 2014, and the Minsk 2 Agreement in 2015. ${ }^{11}$ The most important issue of the Minsk 2 Agreement was the "constitutional reform" to be performed by the end of 2015, granting decentralization, the representatives of the Donbass separatists should be involved. The draft on the issue of decentralization was made ready, but on August 31, 2015 the crowd protesting against its acceptance in front of the parliament began rioting, which forced the parliament to adjourn the modification of the law without date. ${ }^{12}$

- Political crises. The poor economic state, constitutional problems were the reasons and also consequences of internal political crises. The best verification of these crises is the fact that during the 25-year existence of the state, it had to face the emptying of the institution of the referendum, several early elections (head of state in 1994 and in 2014, parliamentary elections in 1994, 2007 and 2014), and two revolutions (the Orange revolution in 2004 and the Revolution of Dignity in 2014). ${ }^{13}$

- Demographic crisis. During the 1989 census (still as a member of the Soviet Union) the population of the Ukrainian SSR was 51.45 million people. The highest number was 52.2 million inhabitants in 1993. During the 2001 census which was the first but also the last census of the independent Ukraine this number decreased to 48.24 million, in 2013 it was about 45 million, while in early 2016 the officially estimated number

dcat' let obščestvennych izmeněnij v Ukraině], Kiev 2011, 441.

7 Online: http://www.tradingeconomics.com/ukraine/gdp (Dowloaded 22 April 2017).

8 MARLIN, Marguerite: Concepts of "Decentralization" and "Federalization" in Ukraine: Political Signifiers or Distinct Constitutionalist Approaches for Devolutionary Federalism?, in: Nationalism and Ethnic Politics, 22, 2016, 3, 278-299.

9 Protocol on the results of consultations of the Trilateral Contact Group, signed in Minsk, 5 September 2014, online: http://www.osce.org/home/123257 (Downloaded 22 April 2017).

10 Memorandum of 19 September 2014 outlining the parameters for the implementation of commitments of the Minsk Protocol of 5 September 2014, online: http://www.osce.org/home/123806 (Downloaded 22 April 2017).

11 UN Security Council resolution 2202 (2015), 12 February 2015, online: http://www.securitycouncilreport.org/ atf/cf/ \%7B65BFCF9B-6D27-4E9C-8CD3-CF6E4FF96FF9 \%7D/s_res_2202.pdf (Downloaded 22 April 2017).

12 ASH, Timothy: Ukraine's constitutional reform conundrum, in: KyivPost, 25 January 2016, online: https://www. kyivpost.com/article/opinion/op-ed/timothy-ash-ukraines-constitutional-reform-conundrum-406630.html (Downloaded 22 April 2017).

13 See Orange Revolution and Aftermath: Mobilisation, Apathy, and the State in Ukraine, D'ANIERI, Paul (Ed.), 2011; MARPLES, David R: Ukraine in Conflict. An Analytical Chronicle, Bristol 2017. 


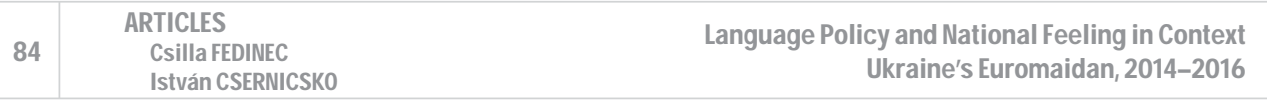

was a bit above 42 million (Crimean and eastern regions included). ${ }^{14}$ The annexed Crimea inhabited by 2.3 million people, and approximately 5 million individuals have been directly affected by the conflict in parts of the Donetsk and Luhansk regions). Nearly 2 million people left the Donbass region, about half of them chose other Ukrainian regions, the others immigrated to other countries. ${ }^{15}$ In 20121.4 million Ukrainian citizens were living permanently or temporarily in Russia, out of them 1.3 million were employed, which meant $11 \%$ of all employed foreigners. From April 2014 up to March 2015 another 2.5 million newcomers increased their number. ${ }^{16}$ With consideration to the war, Poland, the Czech Republic, Greece and Hungary have been assisting their linguistic minorities in relocating. In 2010, long before the eastern Ukrainian armed conflict, according to UN estimates the population of the country will decrease to 35.02 million people. ${ }^{17}$

- Humanitarian crisis. The armed conflict which broke out in 2014 required thousands of lives, many thousands were injured, hundreds of thousands lost their job, their house, asset, and were forced to leave their homes and move abroad or to another region as refugees. The category of the so called Internally Displaced Persons (IDP) became introduced in Ukraine - due to people forced to relocate from the Crimea and the eastern war zone and "inland refugees". In March 2016 the Ministry of Social Policy of Ukraine recorded cca. 1.8 million IDP-s. ${ }^{18}$

\section{Nation and Language}

Kulyk sees the language an important marker of Ukrainian identity which, due to a lack of independent statehood, has been ethnic rather than civic. The contradictory policies of the Soviet regime produced a large discrepancy between ethnocultural identity and language use. In the independent Ukraine this discrepancy persisted, as increased identification with the Ukrainian nation was not accompanied by a commensurate increase in the use of the Ukrainian language. ${ }^{19}$

One of the basic objectives of the emerging pursuit of independence in the Soviet Empire was to make the national languages - giving the names of the republics - state languages. In 1988-1990 the supreme councils (parliaments) of the federal republics passed their language laws, which legally decided their national languages as state languages. Lan-

14 State Statistics Service of Ukraine, online: http://www.ukrstat.gov.ua/ (Downloaded 22 April 2017).

15 Понад два мільйони людей втекли з Донбасу за рік - ООН [Ponad dva mil'joni ljuděj vtěkli z Donbasu za rik OON], 3 May 2015, online: http://www.radiosvoboda.org/a/news/26969151.html (Downloaded 22 April 2017).

16 WEIR, Fred: Ukrainian refugees in Russia: Did Moscow fumble a valuable resource?, in: The Christian Science Monitor, 1 December 2015, online: http://www.csmonitor.com/World/Europe/2015/1201/Ukrainian-refugees-in-Russia-Did-Moscow-fumble-a-valuable-resource (Dowloaded 22 April 2017).

17 CSETE, Örs - PAPP Z., Attila - SETÉNYI, János: Kárpát-medencei magyar oktatás az ezredfordulón, in: Határon túli magyarság a 21. században, BITSKEY, Botond (Ed.), Budapest 2010, 126-127.

18 Ukrinform: Ukraine's Ministry of Social Policy reports nearly 1.8 million internally displaced persons, 31 May 2016, online: https://www.kyivpost.com/article/content/ukraine-politics/ukrinform-ukraines-ministry-of-social-policy-reports-nearly-18-million-internally-displaced-persons-415034.html (Dowloaded 22 April 2017).

19 KULYK, Volodymyr: Language and identity in Ukraine after Euromaidan, in: Thesis Eleven, 136, 2016, 1, 90106. 
guage laws were soon followed by declarations of independence. This way the question of language got the focus of struggle for political independence and national identity. ${ }^{20}$ In Ukraine bearing the features of both bilingualism and multilingualism the struggle has still been fierce in the recent twenty-five years.

In Ukraine the number of persons considering themselves Ukrainian nationals (nearly $78 \%$ ) is much higher than those who consider the Ukrainian state language their mother tongue/ first language (less than $68 \%$ ). The number of citizens considering Russian as their mother tongue/first language (nearly $30 \%$ ) is much higher than those who consider themselves Russian nationals (17.3\%). Nearly quarter (22.18\%) of the total population consider themselves belonging to national minorities. However, practically every third person (32.47 \%) belongs to one or another linguistic minority from a linguistic point of view, as Ukrainian and Russian speakers represent $97.12 \%$ of the total Ukrainian population. National minorities preserving their mother tongues - Bulgarians, Rumanians, Moldovans, Hungarians and the Gagauz - live mainly in blocks, usually in peripheral regions of Ukraine (Transcarpathia, Northern Bukovina, Southern Bessarabia), which were joined to the Soviet Union due to border changes following the second world war. There are altogether four languages Russian, Crimean Tatar, Rumanian and Hungarian - whose speakers represent more than $10 \%$ of the population of the given region. ${ }^{21}$

Similar to several other soviet republics, the Supreme Soviet of the Ukrainian Soviet Socialist Republic passed the law on the languages of the Ukrainian SSR - one of the first laws pursuing independence - as early as in October 1989. ${ }^{22}$ According to this law Ukrainian is the state language ( $2^{\text {nd }}$ Article), Ukrainian and Russian are the languages for international communication ( $4^{\text {th }}$ Article), and the use of minority languages is free choice at offices and in education $\left(3^{\text {rd }}, 10^{\text {th }}, 11^{\text {th }}, 12^{\text {th }}, 18^{\text {th }}, 19^{\text {th }}, 27^{\text {th }}, 28^{\text {th }}, 29^{\text {th }}\right.$ Articles).

However, negative trends concerning language politics could be seen soon after the successful independence referendum (December 1, 1991) and the international recognition of Ukraine as an independent state. Concerning linguistic rights, the 1992 law on national minorities ${ }^{23}$ strengthened the already existing rights to mother tongue education, at the same time the possibility of official language use still depended on the majority of the given national minority inside the given administrative unit ( $8^{\text {th }}$ Article).

The acceptance of The Ukrainian Constitution in June 1996 did not brought essential changes concerning the codification of linguistic rights - except for the limitation of the

20 JAVORSKAJA, Galyna: Языковые конфликты и языковые идеологии в Молдове (на материале анализа фокус-групп) [Jazykovye konflikty i jazykovye iděologii v Moldove (na matěriale analiza fokus-grupp)], in: Studia Linguistika, 2011, 5, 350-351.

21 Online: http://www.ukrcensus.gov.ua/results/general/nationality/ (Downloaded 22 April 2017); CSERNICSKÓ, István - FERENC, Viktória: Transitions in the language policy of Ukraine (1989-2014), in: Sociolinguistic Transition in Former Eastern Bloc Countries: Two Decades after the Regime Change, SLOBODA Marian - LAlHONEN, Petteri - ZABRODSKAJA, Anastassia (Eds.), Frankfurt am Main 2016, 350-353.

22 Закон Української Радянської Сочіалістичної Республіки «Про мови в Українській РСР», № 8312-XI, від 28.10.1989 [Zakon Ukrayins'koyi Radjans'koyi Socialističnoyi Respubliki «Pro movi v Ukrayins'kij RSR», № 8312-Chl, vid 28.10.1989], online: http://zakon2.rada.gov.ua/laws/show/8312-11 (Downloaded 22 April 2017).

23 Закон України «Про начіональні меншини в Україні», № 2494-XII, від 25.06.1992 [Zakon Ukrayini «Pro nacional'ni menšini v Ukrayini», № 2494-Chll, vid 25.06.1992], online: http://zakonO.rada.gov.ua/laws/show/2494-12 (Downloaded 22 April 2017). 


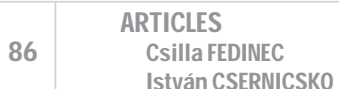

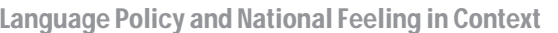

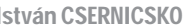

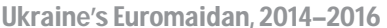

possibilities of Russian: it was no longer defined as the language of international communication - Russian became not more than one of the national minority languages. Those struggling for exclusive Ukrainian monolingualism considered it their victory, while those fighting for the acceptance of Russian as the second official language or a nationally accepted auxiliary language considered it was their defeat.

Ukraine joined the Council of Europe in 1996, but it did not bring about changes concerning the use of mother tongue. The process of the Ukrainian ratification of The European Charter for Regional or Minority Languages was complicated, the obligations of the standard text prescribe less than language rights already existing in Ukraine, do not support national minorities willing to preserve their existing positions, while their rights may be curtailed with reference to the Charter. ${ }^{24}$

After the millennium several laws and other lower rank measures were passed which had negative influence on non-state-language speakers. The 2001 year amendment of the law on parliamentary elections did no longer include the possibility of making ballots available in minority languages. In this period language use regulations were generally amended in favour of the Ukrainian language in several fields. Previously the prescriptions defining the language of the creation, announcement, application etc. of the documents of the different measures (concerning tax, finance, insurance, medicine, elections, food quality, etc.) fell within the competence of the language law, after 2000 each legal rule ordained the exclusive use of the state language. This trend became even stronger after the Orange revolution. Some examples of linguistic equality and inequality from the period: extra duty was imposed on non-Ukrainian publications; from 2008 only Ukrainian language broadcasters could apply for the operation of radio and TV channels; cinemas were allowed to show only Ukrainian-speaking, synchronized or subtitled films.

Education reform should also be mentioned here, as the possibilities of mother-tongue education became limited. Advanced maturity exams - which meant the entrance examinations to higher education as well - had to be taken at independent regional examination centres, in test-system and only in Ukrainian. In addition the Ukrainian language and literature exam became compulsory, the questions of the tests were compiled according to the education program of Ukrainian language schools. ${ }^{25}$

The politically prejudicial situation of minorities was changed by the new language law "On the principles of the state language policy" - passed in 2012.26 The 2012 language law broke off with the declarative framework regulation - traditional in post-soviet regions. Following the spirituality and text of the Language Charter it defined exact rules and cri-

24 ALEKSEEV, Vladimir: Бегом от Европы? Кто и как противодействует в Украине реализации Европейской хартии региональных языков или языков меньшинств [Begom ot Jevropy? Kto i kak protivodějstvujet v Ukraině realizacii Jevropejskoj chartii regionalınych jazykov ili jazykov menıšinstv], Charkov 2008; CSERNICSKÓ, István: The European Charter for Regional or Minority Languages by Ukraine, in: Acta Academiae Beregsasiensis, 2013, 2, $127-145$.

25 CSERNICSKÓ, István - FERENC, Viktória: Education as an ideal means of achieveing a nation state in Ukraine, in: Concepts \& Consequences of Multilingualism in Europe, RÓKA, Jolán (Ed.), Budapest 2010, 329-349.

26 Закон України «Про засади державної мовної політики», № 5029-VI, від 03.07.2012 [Zakon Ukrayini «Pro zasadi děržavnoyi movnoyi politiki», № 5029-VI, vid 03.07.2012], online: http://zakon3.rada.gov.ua/laws/show/5029-17 (Downloaded 22 April 2017); CSERNICSKÓ, István: Language Policy in Ukraine: The Burdens of the Past and the Possibilities of the Future, in: Future Research Directions for Applied Linguistics, PFENNINGER, Simone E. - NAVRACSICS, Judit (Eds.), Bristol 2017, 120-148. 
teria for the addressees of the rights, the concerned geographical areas, the conditions of the use and mechanism of the standard rules and the duties of the executive powers. The law contains among others the exact and clear definition of the language of national minorities ( $1^{\text {st }}$ article) and the list of (altogether 18) languages considered regional or minority languages in Ukraine - including Rusyn, which is officially not recognized as an independent language. The listed languages are: Russian, Belarussian, Bulgarian, Armenian, Gagauz, Yiddish, Crimean Tatar, Moldovian, German, Modern Greek, Polish, Roma, Romanian, Slovak, Hungarian, Rusyn, Karaim, Krymchak. According to the law the use of the above regional languages is compulsory or possible in case the number of the speakers of the given language is at least $10 \%$ of the inhabitants in the given administrative unit $\left(7^{\text {th }}\right.$ article, 3rd §). ${ }^{27}$

Expert opinions protesting against the 2012 language law fear the "Byelorussian way." In the neighbouring country (Byelorussia) actually less than $5 \%$ of the population use the Byelorussian language, which threatens not only the language but also the existence of the Byelorussian nation. "Mother-tongueness" and "language use" should be differentiated, in this respect the European Language Charter - when protecting Russian in Ukraine - supports a language used also by persons identifying themselves as Ukrainian - a great number of these people exclusively use Russian. This situation threatens the Ukrainian language and the existence of the Ukrainian nation. The threat is strengthened by the fact that the law was introduced by representatives of Russian cultural circles. ${ }^{28}$ Positioning regional languages makes it unnecessary to learn Ukrainian, which is even more possible as a great number of the population do not speak the state language, and the situation is not likely to change under these conditions. We can see the hardly implicite "inverse" standpoint according to which minority languages threaten the state language unless it can perform its basic function. ${ }^{29}$

\section{Language as a Casus Belli}

In the late autumn of 2013 - before and after series of political and economic crises - riots broke out in Kyiv that claimed several lives, in March 2014 Russia annexed the Crimea, and the war which is officially called "antiterrorist operation" (ATO) has been lasting since April 2014 at the eastern edges of the country. The Ukrainian-Russian position battle and the unsettled language policy plays a key role in the obstruction of the economic growth of the narrower and wider area, threatening the safety of the whole European continent.

After the disintegration of the Soviet Union millions of the members of the Russian com-

27 CSERNICSKÓ, István - FEDINEC, Csilla: Four Language Laws of Ukraine, in: International Journal on Minority and Group Rights, 23, 2016, 4, 560-582.

28 MOSER, Michael: за mеперішніх обставин офіційна «одномовність», як не парадоксально, $\epsilon$ важливою передумовою для фактичної багатомовності країни, 14 червня 2012 [Za těperišnich obstavin oficijna «odnomovnist'», jak ně paradoksal'no, e važlivoju peredumovoju dlja faktičnoyi bagatomovnosti krayini, 14 červnja 2012], online: http://www.historians.in.ua/index.php/ukrayinska-mova/ (Downloaded 22 April 2017).

29 VOROPAJEVA, Tetjana: Мова, ідентичність і толерантність в контексті імплементації Європейської Хартії регіональних мов або мов меншин в Україні [Mova, iděntičnist' i tolerantnist' v kontěksti implementaciyi Evropejs'koyi Chartiyi regional'nich mov abo mov menšin v Ukrayini], in: Українознавчий альманах [Ukrayinoznavс̌ij al'manach], 9, 2012, 28-36. 
munity in Ukraine have suddenly become a minority, de jure subordinate, that earlier in the Soviet empire linguistically and culturally belonged to the privileged group. ${ }^{30}$ But de facto, these positive economic, political and cultural positions could be saved after the state change. ${ }^{31}$ In this already problematic, tense political situation the fact that the new state organizing ethnic group (Ukrainian) claimed all the treasured positions of the Russian community is the main cause of the conflict.

The conflict between the two dominant ethnic groups broke out because of the functions of the Ukrainian and Russian language. As a result, a paradoxical situation has risen in the language situation and the judgement of the state language policy of the minorities (amongst them the loudest are Russian-speaking) are dissatisfied with their guaranteed language rights, while the majority of the elite is worried about the current status and future of the Ukrainian language. ${ }^{32}$ Korostelina sees the struggle between languages and identities as a zero-sum game that makes compromise impossible. ${ }^{33}$

The political elite divided into two parts used the mobilizing force of the language in all of the parliamentary and presidential election campaigns in the history of independent Ukraine. In the country's northern and western parts the population (where mainly Ukrainian-speaking people live) were threatened by the politicians, that if Russian becomes a second state language in Ukraine it would seal the fate of an independent Ukraine and the Ukrainian nation. A significantly Russian-speaking population of the eastern and southern regions, in contrast tried to encourage voters that the status of their language, the Russian will be regularized and that it will not be superseded from everyday life by the ukrainizing political elite.

The activity around the language issue especially increased as the 2012 parliamentary elections were approaching. In 2010, only $2.43 \%$, and in 2011 less than $1.80 \%$ of the political movements were related to the language situation, in 2012 this proportion rose to 10.45 $\% .^{34}$

An indicator of how interested are the politicians in keeping the language problem in the agenda is that in 2011 (when there were no elections in Ukraine) in $46 \%$ of the movements affecting the language issue were involved parties or other political actors; in the two election years (2010 and 2012), however, this ratio was $64 \%$ and $66 \%{ }^{35}$ In $2012,92 \%$ of the 380 political movements related to the language issue were in defense of the Ukrainian language, against raising the status of Russian language. ${ }^{36}$

The main cause of the language-issue-related demonstrations was the adoption of the new

30 See HAGENDOORN, Louk - LINSSEN, Hub - TUMANOV, Sergei: Intergroup Relations in States of the former Soviet Union: The Perception of Russians, New York 2001.

31 BRUBAKER, Rogers: Nationalism Reframed: Nationhood and the National Question in the New Europe, Cambridge 1996, 17.

32 BOWRING, Bill: The Russian Language in Ukraine: Complicit in Genocide, or Victim of State-building?, in: The Russian Language Outside the Nation, RYAZANOVA-CLARCE, Lara (Ed.), Edingurgh 2014, 56-78.; KULYK Volodymyr: What is Russian in Ukraine? Pupular Beliefs Regarding the Social Roles of the Language, in: The Russian Language, 117-140.

33 KOROSTELINA, Karina V.: Mapping national identity narratives in Ukraine, in: Nationalities Papers, 41, 2013, $2,313$.

34 Протести, перемоги і репресії в Україні: результати моніторингу 2012 p. [Protěsti, peremogi i represiyi v Ukrayini: rezul'tati monitoringu 2012 r.], IŠČENKO, Volodimir (Ed.), Kiev 2013, 34.

35 lbidem, 36.

36 lbidem, 34. 
Language Act. After being defeated in the 2004 Orange Revolution, Viktor Yanukovych won the 2010 presidential election, the President and the Party of Regions behind him according to election promises - he intended to base language policy on the real situation. They wanted to codify the country's de facto bilingualism by raising Russian into a second state language status. The central part of their argument was that violent nationalism threatens linguistic and ethnic rights of the Russian-speaking population, it overshadows the Russian language and culture. ${ }^{37}$ However, the right of free use of the Russian language was demanded not only in the southern and eastern regions, but also across the country, also in areas where the proportion of the Russian-speaking population is insignificant. The new power - ignoring the protest actions - began to rewrite the Constitution and the Language Act. They did not have the political power for the amendment of the Constitution: they did not get two-thirds of the votes in the Parliament. However, the 1989 language law from the Soviet times in 2012 has been replaced after scandalous and unworthy parliamentary scenes and political games. ${ }^{38}$

The language law had a number of opponents. The Constitutional Court was repeatedly asked to declare it unconstitutional, organizing several protests in the streets. The language issue was not reassuring. On 21 November 2013, it became apparent that the president of Ukraine - a country heading towards state bankruptcy at the time - was not going to sign the free trade agreement or the association agreement with the European Union in Vilnius. The Ukrainian government opted for the very favourable Russian loan rather than the IMF loan, which would have brought unpopular and strict austerity measures threatening its power.

On 23 November protests for Ukraine's European integration started in Kyiv. ${ }^{39}$ The protests organized in the city's main square ${ }^{40}$ were peaceful for a while and were called the Revolution of Dignity. On November 30 an unreasonably brutal use of force by the police propelled the lukewarm protests into a national movement. The parliamentary majority backing the president modified several laws on 16 January 2014, in order to limit people's right of assembly. This triggered the protests to escalate to uncontrolled violence which resulted in many casualties (are remembered as "Heaven's Hundred Heroes") as well. The parliament repealed the laws of January 16 on January $28,{ }^{41}$ and on February 22 president Yanukovych fled the country.

A quick realignment occurred in the parliament. Representing different parties than before, the same members of parliament formed a parliamentary majority which repealed the language law on 23 February $2014 .{ }^{42}$ Russia immediately announced that it would defend

37 BOWRING, Bill: The Russian Language, 56-78.

38 See MOSER, Michael: Language Policy.

$39 \mathrm{ONUCH}$, Olga: EuroMaidan Protests in Ukraine: Social Media Versus Social Networks, in: Problems of Post-Communism, 62, 2015, 1-19.

40 Kyiv's central square is called майдан Незалежності (Independence Square) in Ukrainian, however, the locals usually refer to it as Маŭдан (Square), and it was called Maidan in news broadcasts, which, in turn, gave rise to the most often used name of the movement as Euromaidan/Євромайдан.

41 Закон України «Про визнання такими, що втратили чинність, деякихзаконів України», №732-VII, від 28.01.2014 [Zakon Ukrayini «Pro viznannja takimi, ščo vtratili činnist', dějakich zakoniv Ukrayini», №732-VII, vid 28.01.2014], online: http://zakon4.rada.gov.ua/laws/show/732-18 (Downloaded 22 April 2017).

42 Ukraine abolishes law on languages of minorities, including Russian, 23 February 2014, online: http://rbth. co.uk/news/2014/02/23/ukraine_abolishes_law_on_languages_of_minorities_including_russian_34486.html. The 
the Russian speaking minority of Ukraine and protect it from Ukrainian nationalism. On the territory of Crimea, which was transferred in 1954 as the Crimean Autonomous Republic from the Russian Federation to the Ukrainian Soviet Socialist Republic, military personnel from the Russian army ("little green men") bearing no insignia of their affiliation appeared on the same day. ${ }^{43}$

Russian President Vladimir Putin said the following in his speech during the ceremony regarding the annexation of the Crimea on 18 March 2014, where he called it "mainly Russian-speaking Crimea": "the residents of Crimea and Sevastopol turned to Russia for help in defending their rights and lives, in preventing the events that were unfolding and are still underway in Kiev, Donetsk, Kharkov and other Ukrainian cities. Naturally, we could not leave this plea unheeded; we could not abandon Crimea and its residents in distress. This would have been betrayal on our part. [...] Our concerns are understandable because we are not simply close neighbours but, as I have said many times already, we are one people. [...] Millions of Russians and Russian-speaking people live in Ukraine and will continue to do so. Russia will always defend their interests using political, diplomatic and legal means. But it should be above all in Ukraine's own interest to ensure that these people's rights and interests are fully protected. This is the guarantee of Ukraine's state stability and territorial integrity". ${ }^{44}$

Two and a half years after the beginning of the events of Donbass and the Crimea, the Russian president stated his opinion that due to steps taken by the Ukrainian power, Russia "was forced to defend Russian-speaking population of Donbass". ${ }^{45}$ Russia was not the only one that welcomed the abolition of the law with suspect. The Special Rapporteur of UN Stated: "Steps to Abolish the 2012 Law on the Principles of the State Language Policy, although veto, created anxiety amongst some communities, Including ethnic Russians, will hurt minority language rights in fortress. " 46

Temporarily filling the positions of both president and speaker of the parliament, Oleksandr Turchynov assessed the situation and decided, on 27 February not to sign the document that would have repealed the language law of 2012, which thus remained in force. It was too late for a decision, and the attempt of the abolition of the 2012 language law become the pretext of the newest and most serious crisis in Ukraine.

The attempt of the abolition of the language law - when a few hundred meters away from the representatives voting on this in parliament, thousands protested, gunman looked at

text of law, online: http://w1.c1.rada.gov.ua/pls/zweb2/webproc4_1?pf3511=45291 (Downloaded 22 April 2017). 43 FEDINEC, Csilla - HALÁSZ, Iván - TÓTH, Mihály: A független Ukrajna: Államépítés, alkotmányozás és elsülylyesztett kincsek, Budapest 2016, 105-108.

44 Address by President of the Russian Federation, 18 March 2014, online: Address by President of the Russian FederationAddress by President of the Russian FederationAddress by President of the Russian FederationAddress by President of the Russian Federationhttp://en.kremlin.ru/events/president/news/20603 (Downloaded 22 April 2017)

45 Путин:Вынудилизащищать русскоязычныхна Донбассе [Putin: Vynudilizaščiščatı russkojazyčnych na Donbasse], in: Korrespondent.net, 12, October 2016, online: http://korrespondent.net/ukraine/politics/3756878-putyn-vynudyly-zaschyschat-russkoiazychnykh-na-donbasse (Downloaded 22 April 2017).

46 Ukraine: UN Special Rapporteur urges stronger minority rights guarantees to defuse tensions. Geneva, 16 April 2014, online: http://www.ohchr.org/EN/NewsEvents/Pages/DisplayNews.aspx?NewsID=14520 (Downloaded 22 April 2017). 
each other eye to eye, burned in fires - demonstrates how important and symbolic is the language issue in Ukraine.

There are differences in literature concerning the question. According to Sakwa "the language issue was one of the main causes of the conflict that erupted in the eastern part of the country". ${ }^{47}$ Drozda sees: "The present situation in Ukraine is an example of how can a linguistic and cultural war become a precondition and official principle of a real war." 48 At the same time Osnach states: "Wherever we look, the current Russian-Ukrainian war began because of the language. It is an indisputable fact. Russia has just used the language factor as a reason for aggression - by explaining that they need to protect the Russian-speaking citizens of Ukraine." 49

\section{The Language Policy and the Recent Crisis}

Instead of suddenly abolishing the language law Turchynov made a proposal to develop a new language law. He stated that the draft of the new law to be completed within a short period of time, "taking into account the existing speculations regarding the language issue". Turchynov also added that the new, balanced Language Act "will take into account the eastern and western parts of Ukraine, the interests of all ethnic groups and national minorities". ${ }^{50}$ The new language law has still not been born, but this step served to ease the tension, as the statement that prime minister Arseniy Yatseniuk and Turchynov pledged on 18 April 2014, that the highly centralized state power will be decentralized and Russian will get a special status. ${ }^{51}$ The parliament on 20 May voted the "Memorandum of Understanding and Peace", in relation to the languages in which says: "In parallel with the status of the Ukrainian language as a state language the Supreme Council of Ukraine guarantees the insurance of the status of Russian language. The government will also guarantee the support for the languages of national minorities in minority areas compactly. "52 However, this came too late. In April 2014 the recent domestic political developments overshadowed the case of the new language law. With the support of the Russian army an armed conflict broke out in East-Ukrainian Donetsk and Luhansk counties. The euphemistically called "anti-terrorist

\section{SAKWA, Frontline of Ukraine, 220.}

48 DROZDA, Andrij: Розрубати мовний вузол. Скільки російськомовних українців готові наполягати на російськомовності своїх дітей і внуків? [Rozrubati movnij vuzol. Skilıki rosijsıkomovnich ukrayinciv gotovi napoljagati na rosijsıkomovnosti svoyich ditěj i vnukiv?], in: Портал мовної політики [Portal movnoyi politiki], 23 November 2014, online: http://language-policy.info/2014/11/rozrubaty-movnyj-vuzol-skilky-rosijskomovnyh-ukrajintsiv-hotovi-napolyahaty-na-rosijskomovnosti-svojih-ditej-i-vnukiv/ (Downloaded 22 April 2017).

49 OSNACH, Sergij: Мовна складова гібридної війни [Movna skladova gibridnoyi vijni], in: Портал мовної політики [Portal movnoyi politiki], 13 June 2015, online: http://language-policy.info/2015/06/serhij-osnachmovna-skladova-hibrydnoji-vijny/ (Downloaded 22 April 2017).

50 Голова Верховної Ради України Олександр Турчинов доручив підготувати новий Закон України «Про мову» [Golova Verchovnoyi Radi Ukrayini Oleksandr Turčinov doručiv pidgotuvati novij Zakon Ukrayini «Pro movu»], 27 February 2014, online: http://iportal.rada.gov.ua/news/Novyny/Povidomlennya/88685.html (Downloaded 22 April 2017).

51 MARUSYK, Taras: Чиїми «молитвами» закон Колесніченка-Ківалова живе й перемагає [Čiyimi «molitvami» zakon Kolesničenka-Kivalova žive j peremagae], in: Портал мовноїnолітики [Portal movnoyi politiki], 16 June 2015, online: http://language-policy.info/2015/06/taras-marusyk-chyjimy-molytvamy-zakon-kolesnichenka-kivalovazhyve-j-peremahaje/ (Downloaded 22 April 2017).

52 lbidem. 


\begin{tabular}{|c|c|c|}
\hline$t \rightarrow 0$ & 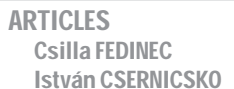 & 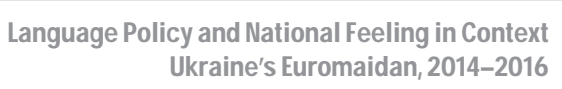 \\
\hline
\end{tabular}

operation" - besides the country's extremely serious economic situation and unbalanced domestic politic - led to a severe crisis.

The new president continued a conciliatory approach. On 28 June 2014 Petro Poroshenko expressed his hope: "I hope - Poroshenko said in a statement on 28 June 2014 - that in the history of Ukraine the issue of language or culture will never again threaten the national unity", thereby acknowledging that the unsettled language problem is a security risk for the state. Poroshenko in his post-election speech and in his New Year's made speech gestures towards the Russian-speaking citizens of Ukraine. At one point in his speech he switched to Russian. He also stated that one can love Ukraine in Russian as much as in Ukrainian. He added that $62 \%$ who fought for Ukraine in the east is Russian-speaking. ${ }^{53}$ The President was the supporter of a movement, which tried to reduce the tension in the country: the "Єдина країна - Единая страна" ("the single country" in Ukrainian and Russian) slogan was depicted on posters, billboards, leaflets, on national television, in the corner of video clips, it also has a dedicated page on the most popular social network site. ${ }^{54}$

This gives reason for nationalist intellectual circles to keep attacking the president. ${ }^{55}$ One of the best known Kyiv based linguistics, Larysa Masenko stated the following in an internet portal where language related issues are discussed regularly: "The currently popular slogan 'ЄӘина країна - Единая страна' is faulty: it solidifies bilingualism on a country level, that is, it strengthens Russian as a second state language. In other words, it does not unify the country but divides it. By saying 'Единая страна' in Russian we turn to those living in the east and assert that Ukrainian, which is a special symbol of the unification of the nation, is not obligatory, even for the president, and with this we betray Ukrainians, primarily those living in the east, who are loyal to their language despite the constant pressure from the Russian speaking environment. "56 Shevchuk, a linguist teaching Ukrainian in the United States agrees: "The Ukrainian society has not only become a hostage" to the united and indivisible Russia's "imperial formula 'Єдина країна, Единая страна' which onfirms the Russification. With its resignation and conformism they take part in destroying their own

53 Решение о лишении русского языка статуса регионального было ошибкой - Порошенко [Rešenije o lišenii russkogo jazyka statusa regional'nogo bylo ošibkoj - Porošenko], in: Korrespondent.net, 28, June 2014, online: http://korrespondent.net/ukraine/politics/3385352-reshenye-o-lyshenyy-russkoho-yazyka-statusa-rehyonalnoho-bylo-oshybkoi-Porosenko (Downloaded 22 April 2017).

54 Єдина Країна| Единая Страна [Edina Krayina | Jedinaja Strana], online: https://vk.com/edina_ukr (Downloaded 22 April 2017).

55 OSNACH, Мовна складова [Movna skladova]; SHEVCHUK, Yuri - OLIYNYK, Yevhenia: Російськомовними патріотами маніпулюють - викладач Колумбійського університету [Rosijs'komovnimi patriotami manipuljujut' - vikladač Kolumbijs'kogo universitětu], in: Портал мовної політики [Portal movnoyi politiki], 20 June 2015, online: http://language-policy.info/2015/06/rosijskomovnymy-patriotamy-manipulyuyut-vykladach-kolumbijskohouniversytetu/; MASENKO, Larysa - HOROBETS, Olena: Офіційна двомовність не об'єднує країну, а сприяєії розпаду [Oficijna dvomovnists ně ob'ednue krayinu, a sprijae yiyi rozpadu], in: Портал мовної політики [Portal movnoyi politiki], 20 June 2015, online: http://language-policy.info/2015/06/larysa-masenko-ofitsijna-dvomovnist-ne-objednuje-krajinu-a-spryyaje-jiji-rozpadu/ (Downloaded 22 April 2017).

56 MASENKO, Larysa - OREL, Мауа: Нам потрібен мовний кордон із Росією. Сучасна мовна політика в Україні очима соціолінгвіста [Nam potriben movnij kordon iz Rosieju. Sučasna movna politika v Ukrayini očima sociolingvista], in: Портал мовної політики [Portal movnoyi politiki], 26 December 2014, online: http://languagepolicy.info/2014/12/nam-potriben-movnyj-kordon-iz-rosijeyu-suchasna-movna-polityka-ukrajini-ochymasotsiolinhvista/ (Downloaded 22 April 2017). 
language and culture ". ${ }^{57}$ Citing a metaphorical parallel between the inhabitants of Gilead and Ephraim of the biblical Book of Judges (112: 56), known for bloody conflicts (see now Shibboleth) and between the Ukrainian war, Shevchuk opposed the Ukrainian-Russian bilingualism for all kinds of manifestations: "The linguistic schizophrenia deprives the protective role from the Ukrainian language in the existential situations when your life is in danger, and based on your language you can distinguish ours from the enemy. " 58

Masenko is suspiciously eyeing the Russian-speaking part of the Ukrainian society: "The victory in the linguistic and cultural war with Ukraine was a prerequisite for Russia in the current military intervention, and the occupation of Donbass and the Crimea. And planning the revitalization of the Soviet empire, the Kremlin is counting on those parts of the Ukrainian population which could be 'crystallized' by the control of the mass media." 59 Many consider that the sacrifice made by Russian native speakers on the front line for Ukraine is not enough. A Ukrainian writer Matsyuk explains in one of the entries in a language policy portal on Russian-speaking people fighting against separatists "somehow we should make them believe, that their Moscow language is their personal sin against Ukraine [...] against the Ukraine, for which, literally, they shed their blood". According to him, the Russian-speaking Ukrainians also have to be convinced that the Russian language in Ukraine does not worth the blood sacrifice. And then he asks the question: [the Russian-speaking Ukrainians] "when will they leave the Russian speech which has only been their mother tongue since the second generation? This will be the redemption of their original sin, which is more expensive for Ukraine than their blood". 60

The battlefield sacrifice of the Russian-speaking is being reduced by sociological research. For example, a survey published 6 June 2016, points out that among the participants of the ATO $73 \%$ is of Ukrainian mother tongue, $6 \%$ of Russian and $19 \%$ of the Ukrainian-Russian-speaking rate; however, among those informants who are not involved in the ATO, only $55 \%$ is the proportion of native speakers of the Ukrainians, $19 \%$ is Russian-speaking and $23 \%$ is bilingual. So there is a bigger proportion of the Ukrainian-speakers in the ATO than amongst those who are not involved in the fights. ${ }^{61}$

Every year on 9 November the Ukrainian Literacy Day is celebrated. In 2015 on this occasion a one and a half minute video was made where volunteers ${ }^{62}$ in eastern Ukraine who

57 See SHEVCHUK, Yuri: Movna šizofrenija. Quo vadis, Ukrayino?, Ivano-Frankivs'k 2015.

58 SHEVCHUK, Yuri - PALAZHYI, Halyna: Мовна шизофренія - нова, потужна форма русифікації [Моvnа šizofrenija - nova, potužna forma rusifikaciyi], in: Портал мовної політики [Portal movnoyi politiki], 19 September 2015, online: http://language-policy.info/2015/09/yurij-shevchuk-movna-shyzofreniya-nova-potuzhna-formarusyfikatsiji/\#more-1780 (Downloaded 22 April 2017).

59 MASENKO, Larysa: Мовознавча солідарність по-українськи [Movoznavča solidarnistı po-ukrayinsıki], in: Портал мовної політики [Portal movnoyi politiki], 24 September 2015, online: http://language-policy. info/2015/09/larysa-masenko-movoznavcha-solidarnist-po-ukrajinsky/ (Downloaded 22 April 2017).

60 MATSYUK, Romko: Гріх [Grich], in: Портал мовної політики [Portal movnoyi politiki], 12 November 2015, online: http://language-policy.info/2015/11/roman-matsyuk-hrih/ (Downloaded 22 April 2017).

61 Дослідження: українська мова є рідною для 73 \% учасників ATO, російська - для 6 \% [Doslidžennja: ukrayins'ka mova e ridnoju dlja 73 \% učasnikiv ATO, rosijs'ka - dlja 6 \%,], 7 June 2016, online: http://language-policy. info/2016/06/doslidzhennya-ukrajinska-mova-je-ridnoyu-dlya-73-uchasnykiv-ato-rosijska-dlya-6/ (Downloaded 22 April 2017).

62 As a result a hybrid war from 2014, the president Ukraine create volunteer units under the program "Territorial Defense". In November 2014 most of the territorial battalions were integrated into Ukraine's Ground forces. 


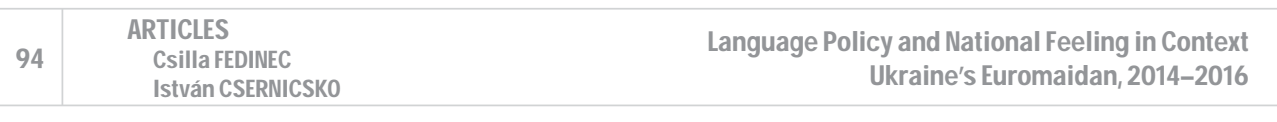

took part in battles, tell their ideas on Ukrainian politics. The words of the volunteers indicate, how the Ukrainian national side sees the role of the Ukrainian and Russian language, objectives and tasks of the wartime language policy. The first interviewee said: "I grew up in a Russian-speaking family. After the Maidan I switched to the use of the Ukrainian language, because I realized that the best resistance against the Russian aggression is if we speak Ukrainian." Another volunteer stated: "enemies [...] openly claim that where the Russian language is, there is the Russian interest". Essence of the message: "If you do not want the Russian soldiers to come and 'liberate' you and your loved ones use the most powerful weapon against them: speak Ukrainian!"63

Civil movements are protesting against the missing Ukrainian nationalization. On the 9th of November 2015 a movement in front of the presidential office announced claims to provide special status of the Ukrainian language, the motto was "Ukrainization - resistance against the occupation". ${ }^{64}$ "The [...] language law was written on Putin's knee, and had a different purpose. The president keeps talking about the protection of the Ukrainian language, but nothing happens. We are tired of demagoguery. A war is going on here, the Russian propaganda pours from the screen, and no one does anything about it" - said one of the protesters. ${ }^{65}$

Extension of the scope of use of the Ukrainian language, the obstruction of the Russian language is considered by many as a split from the colonial past Soviet era and means freedom and independence. According to Masenko, "the Russian language is the chain that bounds Ukraine to the Communist past". 66

At the $25^{\text {th }}$ anniversary of the Ukrainian independence scheduled for 24 August 2016 a nationwide campaign of young people was announced, the slogan was: "Be truly independent: speak Ukrainian!"67

\section{Conclusion}

Based on the foregoing, the crisis in Ukraine and the language problems are connected by multiple threads. In the only 25-year history, the country has faced various crises. In the

63 Військові та волонтери закликають спілкуватися українською - відео [Vijs'kovi ta volontěri zaklikajut' spilkuvatisja ukrayins'koju - viděo], 9 November 2015, online: http://language-policy.info/2015/11/vijskovi-ta-volontery-zaklykayut-spilkuvatysya-ukrajinskoyu-video/ (Downloaded 22 April 2017).

64 Що можна зробити у День української nuсемності та мови [Ščо možna zrobiti u Děn' ukrayins'koyi pisemnosti ta movi], 7 November 2015, online: http://language-policy.info/2015/11/scho-mozhna-zrobyty-u-den-ukrajinskoji-pysemnosti-ta-movy/ (Downloaded 22 April 2017).

65 На Банковій протестували проти русифікації [Na Bankovij protěstuvali proti rusifikaciyi], 9 November 2015, online: http://language-policy.info/2015/11/na-bankovij-protestuvaly-proty-rusyfikatsiji/ (Downloaded 22 April 2017).

66 MASENKO, Larysa: Скандал в Охматдиті як дзеркало пострадянської мовної політики [Skandal v Ochmatditi jak dzerkalo postradjans'koyi movnoyi politiki], in: Портал мовної політики [Portal movnoyi politiki], 29 August 2016, online: http://language-policy.info/2016/08/skandal-v-ohmatdyti-yak-dzerkalo-postradyanskoji-movnojipolityky/ (Downloaded 22 April 2017).

67 Мовомарафон-25: до річниці Незалежності українці переходитимуть на українську мову [Movomarafon-25: do ričnici Nězaležnosti ukrayinci perechoditimut' na ukrayins'ku movu], 11 August 2016, online: http://language-policy.info/2016/08/movomarafon-25-do-richnytsi-nezalezhnosti-ukrajintsi-perehodytymut-na-ukrajinsku-movu/ (Downloaded 22 April 2017). 
domestic political crises the language issue was constantly present: the political elite used the language issue as a mobilizing force for the election mood-enhancing factor to their own use. The language issue could become a division factor instead of a cohesion factor for a nation that is seeking identity after the collapse of the Soviet system.

As a result of the misguided language policy in the tense political situation the language issue became a pretext for military intervention, it has become a casus belli. In the conflict of the increased Russian nationalism and the growing Ukrainian nationalism the language plays a central role. In response to the circumstances of the Ukrainian crisis, the Kyiv government is trying to develop a language policy that reduces social division and tension and towards both sides (native speakers of Ukrainian and Russian speakers). However, the Ukrainian nationalism sees Russian language as the aggressor, as the enemy's language and the spread of the Ukrainian language is connected to the country's independence, winning the war in the east and the independence. Simultaneously, however, the imperial nationalism in Russia, apparently for state-supported shows on the Ukrainian nationalism as a response to the annexation of the Crimea and the military intervention into Ukrainian territory.

Ukraine today is a state that has been in a transitional period since the proclamation of its independence twenty-five years ago: it seeks the leaven, which can be the basis for a new national identity. Unfortunately, the Ukrainian language policy did not contribute to this search and could not come up with valid solutions for the crisis. However aftermath of the Crisis the currently bilingual country can become monolingual gradually.

\section{References}

Address by President of the Russian Federation, 18 March 2014, online: http://en.kremlin.ru/events/president/news/20603 (Downloaded 22 April 2017).

ALEKSEEV, Vladimir: Бегом от Европы? Кто и как противодействует в Украине реализации Европейской хартии региональных языков или языков меньшинств [Begom ot Jevropy? Kto i kak protivodějstvujet v Ukraině realizacii Jevropejskoj chartii regional'nych jazykov ili jazykov men'šinstv], Charkov 2008.

All-Ukrainian population Census, online: http://www.ukrcensus.gov.ua/results/general/ nationality/ (Downloaded 22 April 2017)

ASH, Timothy, Ukraine's constitutional reform conundrum, in: KyivPost, 25 January 2016, online: https://www.kyivpost.com/article/opinion/op-ed/timothy-ash-ukrainesconstitutional-reform-conundrum-406630.html (Downloaded 22 April 2017).

BOWRING, Bill: The Russian Language in Ukraine: Complicit in Genocide, or Victim of State-building?, in: The Russian Language Outside the Nation, RYAZANOVA-CLARKE, Lara (Ed.), Edinburg University Press 2014, 56-78.

BRUBAKER, Rogers: Nationalism Reframed: Nationhood and the National Question in the New Europe, Cambridge 1996.

Cambridge Dictionary, online: http://dictionary.cambridge.org/dictionary/english/crisis (Downloaded 22 April 2017).

CSERNICSKÓ, István: The European Charter for Regional or Minority Languages by Ukraine, in: Acta Academiae Beregsasiensis, 2013, 2, 127-145. 
CSERNICSKÓ, István: Language Policy in Ukraine: The Burdens of the Past and the Possibilities of the Future, in: Future Research Directions for Applied Linguistics, PFENNINGER, Simone E. - NAVRACSICS, Judit (Eds.), Bristol 2017, 120-148.

CSERNICSKÓ, István - FEDINEC, Csilla: Four Language Laws of Ukraine, in: International Journal on Minority and Group Rights, 23, 2016, 4, 560-582.

CSERNICSKÓ, István - FERENC, Viktória: Education as an ideal means of achieving a nation state in Ukraine, in: Concepts \& Consequences of Multilingualism in Europe, RÓKA, Jolán (Ed.), Budapest 2010, 329-349.

CSERNICSKÓ, István - FERENC, Viktória: Transitions in the language policy of Ukraine (1989-2014), in: Sociolinguistic Transition in Former Eastern Bloc Countries: Two Decades after the Regime Change, SLOBODA Marian - LAIHONEN, Petteri - ZABRODSKAJA, Anastassia (Eds.), Frankfurt am Main 2016, 350-353.

CSETE, Örs - PAPP Z., Attila - SETÉNYI, János: Kárpát-medencei magyar oktatás az ezredfordulón, in: Határon túli magyarság a 21. században, BITSKEY, Botond (Ed.), Budapest 2010, 126-127.

Дослідження: українська мова є рідною для 73 \% учасників ATO, російська - для 6 \% [Doslidžennja: ukrayins'ka mova e ridnoju dlja 73 \% učasnikiv ATO, rosijs'ka - dlja 6 \%,], 7 June 2016, online: http://language-policy.info/2016/06/doslidzhennya-ukrajinska-movaje-ridnoyu-dlya-73-uchasnykiv-ato-rosijska-dlya-6/ (Downloaded 22 April 2017).

DROZDA, Andrij: Розрубати мовний вузол. Скільки російськомовних українців готові наполягати на російськомовності своїх дітей і внуків [Rozrubati movnij vuzol. Skil'ki rosijs'komovnich ukrayinciv gotovi napoljagati na rosijs'komovnosti svoyich ditěj i vnukiv?], in: Портал мовної політики [Portal movnoyi politiki], 23 November 2014, online: http:// language-policy.info/2014/11/rozrubaty-movnyj-vuzol-skilky-rosijskomovnyh-ukrajintsivhotovi-napolyahaty-na-rosijskomovnosti-svojih-ditej-i-vnukiv/ (Downloaded 22 April 2017).

Єдина Країна | Единая Страна [Edina Krayina | Jedinaja Strana], https://vk.com/edina_ukr (Downloaded 22 April 2017).

FEDINEC, Csilla - HALÁSZ, Iván - TÓTH, Mihály: A független Ukrajna: Államépítés, alkotmányozás és elsüllyesztett kincsek, Budapest 2016.

Голова Верховної Ради України Олександр Турчинов доручив підготувати новий Закон України «Про мову» [Golova Verchovnoyi Radi Ukrayini Oleksandr Turčinov doručiv pidgotuvati novij Zakon Ukrayini «Pro movu»], 27 February 2014, online: http://iportal.rada.gov.ua/news/Novyny/Povidomlennya/88685.html (Downloaded 22 April 2017).

GRIN, François: Language Policy Evaluation and the European Charter for Regional or Minority Languages, Palgrave Macmillan 2003.

HAGENDOORN, Louk - LINSSEN, Hub - TUMANOV, Sergei: Intergroup Relations in States of the former Soviet Union: The Perception of Russians, New York 2001.

JAVORSKAJA, Galyna: Языковые конфликты и языковые идеологии в Молдове (на материале анализа фокус-групп), in: Studia Linguistika, 2011, 5, 350-351.

KISSINGER, Henry: To Settle the Ukraine Crisis, Start at The End, in: The Washington Post, 5 March 2014, online: http://www.washingtonpost.com/opinions/henry-kissingerto-settle-the-ukraine-crisis-startat-the-end/2014/03/05/46dad868-a496-11e3-8466d34c451760b9_story.html (Downloaded 22 April 2017). 
KOROSTELINA, Karina V.: Mapping national identity narratives in Ukraine, in: Nationalities Papers, 41, 2013, 2, 313.

KULYK, Volodymyr: What is Russian in Ukraine? Pupular Beliefs Regarding the Social Roles of the Language, in: The Russian Language, 2014, 117-140.

KULYK, Volodymyr: Language and identity in Ukraine after Euromaidan, in: Thesis Eleven, 136, 2016, 1, 90-106.

LARUELLE, Marlene: The Ukrainian Crisis and its Impact on Transforming Russian Nationalism Landscape, in: Ukraine and Russia: People, Politics, Propaganda and Perspectives, WILCZEWSKA, Agnieszka P. - SAKWA, Richard (Eds.), E-IR Info 2015, 123-128.

MARIONI, Max: The cost of Russian sanctions on Western economies, in: BOW Group Research Paper: The Sanctions on Russia, August 2015, 16-31.

MARLIN, Marguerite: Concepts of "Decentralization" and "Federalization" in Ukraine: Political Signifiers or Distinct Constitutionalist Approaches for Devolutionary Federalism?, in: Nationalism and Ethnic Politics, 22, 2016, 3, 278-299.

MARPLES, David R.: Ukraine in Conflict. An Analytical Chronicle, Bristol 2017.

MARUSYK, Taras: Чиїми «молитвами» закон Колесніченка-Ківалова живе й перемагає [С̌іуіmі «molitvami» zakon Kolesničenka-Kivalova žive j peremagae], in: Портал мовної політики [Portal movnoyi politiki], 16 June 2015, online: http://language-policy.info/2015/06/ taras-marusyk-chyjimy-molytvamy-zakon-kolesnichenka-kivalova-zhyve-j-peremahaje/ (Downloaded 22 April 2017).

MASENKO, Larysa: Мовознавча солідарність по-українськи, [Movoznavča solidarnist' po-ukrayins'ki], in: Портал мовної політики [Portal movnoyi politiki], 24 September 2015, online: http://language-policy.info/2015/09/larysa-masenko-movoznavcha-solidarnistpo-ukrajinsky/ (Downloaded 22 April 2017).

MASENKO, Larysa: Скандал в Охматдиті як дзеркало пострадянської мовної політики [Skandal v Ochmatditi jak dzerkalo postradjans'koyi movnoyi politiki], in: Портал мовної політики [Portal movnoyi politiki], 29 August 2016, online: http://language-policy. info/2016/08/skandal-v-ohmatdyti-yak-dzerkalo-postradyanskoji-movnoji-polityky/ (Downloaded 22 April 2017).

MASENKO, Larysa - HOROBETS, Olena: Офіційна двомовність не об'єднує країну, а сприяє iï розпаду [Oficijna dvomovnist' ně ob'ednue krayinu, a sprijae yiyi rozpadu], in: Портал мовної політики [Portal movnoyi politiki], 20 June 2015, online: http://language-policy. info/2015/06/larysa-masenko-ofitsijna-dvomovnist-ne-ob-jednuje-krajinu-a-spryyaje-jijirozpadu/ (Downloaded 22 April 2017).

MASENKO, Larysa - OREL, Мауа: Нам потрібен мовний кордон із Росією. Сучасна мовна політика в Україні очима соціолінгвіста [Nam potriben movnij kordon iz Rosieju. Sučasna movna politika v Ukrayini očima sociolingvista], in: Портал мовної політики [Portal movnoyi politiki], 26 December 2014, online: http://language-policy.info/2014/12/nam-potribenmovnyj-kordon-iz-rosijeyu-suchasna-movna-polityka-ukrajini-ochyma-sotsiolinhvista/ (Downloaded 22 April 2017).

MATSYUK, Romko: Гpix [Grich], in: Портал мовної політики [Portal movnoyi politiki], 12 November 2015, online: http://language-policy.info/2015/11/roman-matsyuk-hrih/ (Downloaded 22 April 2017).

Memorandum of 19 September 2014 outlining the parameters for the implementation of 


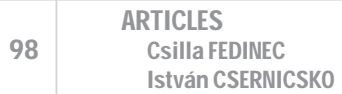

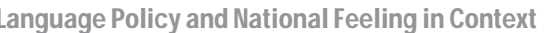

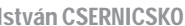

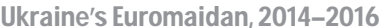

commitments of the Minsk Protocol of 5 September 2014, online: http://www.osce.org/ home/123806 (Downloaded 22 April 2017).

MOSER, Michael: Language Policy and the Discourse on Languages in Ukraine under President Viktor Yanukovych, 25 February 2010 - 28 October 2012, Stuttgart 2013.

MOSER, Michael: 3а mеперішніх обставин офіційна «одномовність», як не парадоксально, $\epsilon$ важливою передумовою для фактичної багатомовності країни, 14 червня 2012 [Zа těperišnich obstavin oficijna "odnomovnist'», jak ně paradoksal'no, e važlivoju peredumovoju dlja faktičnoyi bagatomovnosti krayini, 14 červnja 2012], online: http:// www.historians.in.ua/index.php/ukrayinska-mova/ (Downloaded 22 April 2017).

Мовомарафон-25: до річниці Незалежності україниі переходитимуть на українську мову [Movomarafon-25: do ričnici Nězaležnosti ukrayinci perechoditimut' na ukrayins'ku movu], 11 August 2016, online: http://language-policy.info/2016/08/movomarafon-25do-richnytsi-nezalezhnosti-ukrajintsi-perehodytymut-na-ukrajinsku-movu/ (Downloaded 22 April 2017).

На Банковій протестували проти русифікації [Na Bankovij protěstuvali proti rusifikaciyi], 9 November 2015, online: http://language-policy.info/2015/11/na-bankovij-protestuvalyproty-rusyfikatsiji/ (Downloaded 22 April 2017).

ONUCH, Olga: EuroMaidan Protests in Ukraine: Social Media Versus Social Networks, in: Problems of Post-Communism, 62, 2015, 1-19.

Orange Revolution and Aftermath: Mobilisation, Apathy, and the State in Ukraine, D'ANIERI, Paul (Ed.), 2011.

OSNACH, Sergij: Мовна складова гібридної війни [Movna skladova gibridnoyi vijni], in: Портал мовної політики [Portal movnoyi politiki], 13 June 2015, online: http://languagepolicy.info/2015/06/serhij-osnach-movna-skladova-hibrydnoji-vijny/ (Downloaded 22 April 2017).

Понад два мільйони людей втекли з Донбасу за рік - ООН [Ponad dva mil'joni ljuděj vtěkli z Donbasu za rik - OON], 3 May 2015, online: http://www.radiosvoboda.org/a/ news/26969151.html (Downloaded 22 April 2017).

Протести, перемоги і репресії в Україні: результати моніторингу 2012 р., [Protěsti, peremogi i represiyi v Ukrayini: rezul'tati monitoringu 2012 r.], IŠČENKO, Volodimir (Ed.), Kiev 2013, 34. Protocol on the results of consultations of the Trilateral Contact Group, signed in Minsk, 5 September 2014, online: http://www.osce.org/home/123257 (Downloaded 22 April 2017).

Путин: Вынудили защищать русскоязычных на Донбасcе [Putin: Vynudili zaščǐčat' russkojazyčnych na Donbasse] in: Korrespondent.net, 12 October 2016, online: http://korrespondent.net/ukraine/politics/3756878-putyn-vynudyly-zaschyschatrusskoiazychnykh-na-donbasse (Downloaded 22 April 2017).

Решение о лишении русского языка статуса регионального было ошибкой - Порошенко [Rešenije o lišenii russkogo jazyka statusa regional'nogo bylo ošibkoj - Porošenko], in: Korrespondent.net, 28 June 2014, online: http://korrespondent.net/ukraine/ politics/3385352-reshenye-o-lyshenyy-russkoho-yazyka-statusa-rehyonalnoho-bylooshybkoi-Porosenko (Downloaded 22 April 2017).

RUTLAND, Peter: An Unnecessary War: The Geopolitical Roots of the Ukraine Crisis, in: E-International Relations, 2015, online: http://www.e-ir.info/2015/04/09/an-unnecessary- 
war-the-geopolitical-roots-of-the-ukraine-crisis/ (Downloaded 22 April 2017). SAKWA, Richard: Frontline of Ukraine: Crisis is the Borderlands, I.B. Tauris 2014. Що можна зробити у День української писемності та мови [Ščo možna zrobiti u Děn' ukrayins'koyi pisemnosti ta movi], 7 November 2015, online: http://language-policy. info/2015/11/scho-mozhna-zrobyty-u-den-ukrajinskoji-pysemnosti-ta-movy/ (Downloaded 22 April 2017).

SHEVCHUK, Yuri: Мовна шизофренія. Quo vadis, Україно, Ivano-Frankivsk 2015.

SHEVCHUK, Yuri - OLIYNYK, Yevhenia: Російськомовними патріотами маніпулюють - викладач Колумбійського університету [Rosijs'komovnimi patriotami manipuljujut' vikladač Kolumbijs'kogo universitětu], in: Портал мовноїполітики [Portal movnoyi politiki], 20 June 2015, online: http://language-policy.info/2015/06/rosijskomovnymy-patriotamymanipulyuyut-vykladach-kolumbijskoho-universytetu/.

SHEVCHUK, Yuri-PALAZHYI, Halyna: Мовна шизофренія - нова, потужна форма русифікації

[Movna šizofrenija - nova, potužna forma rusifikaciyi], in: Портал мовної політики [Portal movnoyi politiki], 19 September 2015, online: http://language-policy.info/2015/09/ yurij-shevchuk-movna-shyzofreniya-nova-potuzhna-forma-rusyfikatsiji/\#more-1780 (Downloaded 22 April 2017).

SHUL'GA, Nykolaj: Дрейф на обочину. Двадчать лет общественных изменений в Украине [Drejf na obočinu. Dvadcat' let obščestvennych izmeněnij v Ukraině], Kiev 2011.

State Statistics Service of Ukraine, online: http://www.ukrstat.gov.ua/ (Downloaded 22 April 2017).

Ukraine abolishes law on languages of minorities, including Russian, 23 February 2014, online: http://rbth.co.uk/news/2014/02/23/ukraine_abolishes_law_on_languages_of_ minorities_including_russian_34486.html.

Ukraine: UN Special Rapporteur urges stronger minority rights guarantees to defuse tensions. Geneva, 16 April 2014, online: http://www.ohchr.org/EN/NewsEvents/Pages/ DisplayNews.aspx?NewsID=14520 (Downloaded 22 April 2017).

Ukrinform: Ukraine's Ministry of Social Policy reports nearly 1.8 million internally displaced persons, 31 May 2016, online: https://www.kyivpost.com/article/content/ukraine-politics/ ukrinform-ukraines-ministry-of-social-policy-reports-nearly-18-million-internallydisplaced-persons-415034.html (Dowloaded 22 April 2017).

UN Security Council resolution 2202 (2015), 12 February 2015, online: http://www. securitycouncilreport.org/atf/cf/\%7B65BFCF9B-6D27-4E9C-8CD3-CF6E4FF96FF9 \%7D/s_res_2202.pdf (Downloaded 22 April 2017).

Військові та волонтери закликають спілкуватися українською - відео [Vijs'kovi ta volontěri zaklikajut' spilkuvatisja ukrayins'koju - viděo], 9 November 2015, online: http://languagepolicy.info/2015/11/vijskovi-ta-volontery-zaklykayut-spilkuvatysya-ukrajinskoyu-video/ (Downloaded 22 April 2017).

VOROPAJEVA, Tetjana: Мова, ідентичність і толерантність в контексті імплементації Європейської Хартії регіональних мов або мов меншин в Україні [Mova, iděntičnist' і tolerantnist' v kontěksti implementaciyi Evropejs'koyi Chartiyi regional'nich mov abo mov menšin v Ukrayini], in: Українознавчий альманах [Ukrayinoznavčij al'manach], 9, 2012, 28-36.

WEIR, Fred: Ukrainian refugees in Russia: Did Moscow fumble a valuable resource?, in: The 
Christian Science Monitor, 1 December 2015, online: http://www.csmonitor.com/World/ Europe/2015/1201/Ukrainian-refugees-in-Russia-Did-Moscow-fumble-a-valuable-resource (Dowloaded 22 April 2017).

The World Bank. http://data.worldbank.org/country/russian-federation?view=chart (Downloaded 22 April 2017).

Trading Economics, online: http://www.tradingeconomics.com/ukraine/gdp (Dowloaded 22 April 2017).

Закон Української Радянської Сочіалістичної Республіки «Про мови в Українській РСР», № 8312-XІ, від 28.10.1989 [Zakon Ukrayins'koyi Radjans'koyi Socialističnoyi Respubliki «Pro movi v Ukrayins'kij RSR», № 8312-Chl, vid 28.10.1989], online: http://zakon2.rada.gov.ua/ laws/show/8312-11 (Downloaded 22 April 2017).

Закон України «Про начіональні меншини в Україні», № 2494-XII, від 25.06.1992 [Zakon Ukrayini «Pro nacional'ni menšini v Ukrayini», № 2494-Chll, vid 25.06.1992], online: http:// zakon0.rada.gov.ua/laws/show/2494-12 (Downloaded 22 April 2017).

Закон України «Про засади державної мовної політики», №5029-VI, від 03.07.2012 [Zakon Ukrayini «Pro zasadi děržavnoyi movnoyi politiki», № 5029-VI, vid 03.07.2012], online: http://zakon3.rada.gov.ua/laws/show/5029-17 (Downloaded 22 April 2017).

Закон України «Про визнання такими, що втратили чинність, деякихзаконів України», №732VII, від 28.01.2014 [Zakon Ukrayini «Pro viznannja takimi, ščo vtratili činnist', dějakich zakoniv Ukrayini», №732-VII, vid 28.01.2014], online: http://zakon4.rada.gov.ua/laws/ show/732-18 (Downloaded 22 April 2017).

\section{Authors}

Csilla Fedinec, PhD.

Társadalomtudományi Kutatóközpont, Magyar Tudományos Akadémia

Centre for Social Sciences, Institute for Minority Studies, Hungarian Academy of Sciences $\mathrm{H}-1453$ Budapest PO Box 25, Hungary

Fedinec.csilla@tk.mta.hu

Dr. habil. István Csernicsko, egyetemi docens

II. Rákóczi Ferenc Kárpátaljai Magyar Főiskola, Pannon Egyetem

Ferenc Rákóczi II Transcarpathian Hungarian Institute, University of Pannonia

Kossuth négyzet 6, UA-90202 Beregove, Transcarpathia, Ukraine

csernicsko.istvan@kmf.uz.ua 